
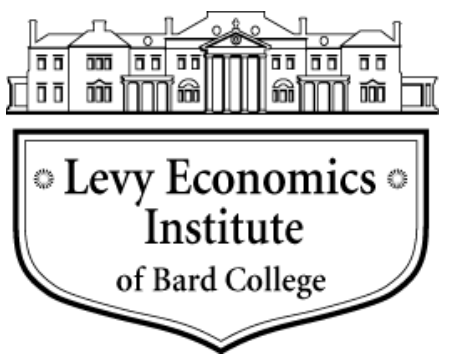

Working Paper No. 935

\title{
Evolving International Monetary and Financial Architecture and the Development Challenge: A Liquidity Preference Theoretical Perspective
}

by

\author{
Jörg Bibow \\ Skidmore College
}

August 2019

The Levy Economics Institute Working Paper Collection presents research in progress by Levy Institute scholars and conference participants. The purpose of the series is to disseminate ideas to and elicit comments from academics and professionals.

Levy Economics Institute of Bard College, founded in 1986, is a nonprofit, nonpartisan, independently funded research organization devoted to public service. Through scholarship and economic research it generates viable, effective public policy responses to important economic problems that profoundly affect the quality of life in the United States and abroad.

\author{
Levy Economics Institute \\ P.O. Box 5000 \\ Annandale-on-Hudson, NY 12504-5000 \\ http://www.levyinstitute.org
}

Copyright (C) Levy Economics Institute 2019 All rights reserved

ISSN 1547-366X 


\begin{abstract}
This paper investigates the peculiar macroeconomic policy challenges faced by emerging economies in today's monetary (non)order and globalized finance. It reviews the evolution of the international monetary and financial architecture against the background of Keynes's original Bretton Woods vision, highlighting the US dollar's hegemonic status. Keynes's liquidity preference theory informs the analysis of the loss of policy space and widespread instabilities in emerging economies that are the consequence of financial hyperglobalization. While any benefits promised by mainstream promoters remain elusive, heightened vulnerabilities have emerged in the aftermath of the global crisis.
\end{abstract}

KEYWORDS: Emerging Economies; Hyperglobalization; Liquidity; Liquidity Preference Theory; Reserve Accumulation; US Dollar Hegemony

JEL CLASSIFICATIONS: B22; E43; E44; F02; F36; F65; G12 


\section{INTRODUCTION AND OVERVIEW}

This paper investigates the peculiar macroeconomic policy challenges faced by emerging economies in today's monetary (non)order and globalized finance. We review the evolution of the international monetary and financial architecture against the background of Keynes's original Bretton Woods vision highlighting the US dollar's hegemonic status. Keynes's liquidity preference theory informs the analysis of the loss of policy space and widespread instabilities in emerging economies that are the consequence of financial hyperglobalization. While any benefits promised by mainstream promoters remain elusive, heightened vulnerabilities have emerged in the aftermath of the global crisis.

\section{KEYNES'S LIQUIDITY PREFERENCE THEORY IN A GLOBAL SETTING}

Keynes's ([1936] 1971) The General Theory of Employment, Interest and Money delivered two pivotal blows to the mainstream (neo)classical thought of his time: one concerning labor markets, the other concerning financial markets.

In the mainstream view, employment is determined in labor markets and unemployment arises because workers are asking for too much. Work would be readily available to anyone willing to work at a lower (market-clearing) wage; unemployment is therefore always voluntary. Exemplifying a more general warning to economists to not blindly apply microeconomic thinking to macroeconomic issues, Keynes identified a fallacy of composition in this argument: whereas individual workers might be able to price themselves into employment, wage cuts across the economy are prone to yield deflation and instability instead. Any macroeconomic employment gains are unlikely to arise other than through raising a country's external competitiveness - a "beggar-thy-neighbor" zero-sum game which, at the global (supramacro) economy level, still constitutes said fallacy of composition. The global economic calamity playing out at the time illustrated Keynes's point rather well. 
At the macro level, the crucial employment constraint overlooked by the mainstream theory of employment is the level of "effective demand," which depends on entrepreneurs' sales expectations in general and perceptions of profit opportunities on real investment projects in particular. Moreover, in "monetary production economies," money cannot be "abstracted from" and only added on later as an afterthought to the "real analysis." Instead, being far from "neutral," money must be part of the analysis from the start, affecting motives, decisions, and employment outcomes.

The financial system comes to the fore here as either facilitating or potentially constraining economic activity, employment, capital accumulation, and development. Keynes also takes issue with mainstream thinking on money and interest that prevailed at the time. He rejected both the "quantity theory of money" and the "loanable funds theory of interest."

The former is preoccupied with the medium-of-exchange role of money and naïvely posits a proportionality between the monetary facilitator of market exchanges and the price level, with causality supposedly running from money to prices. Already in his "Tract on Monetary Reform," Keynes ([1923] 1971) found that the quantity theory of money was useless for policy purposes. In the General Theory, he highlighted that the quantity theory of money was not only out of touch with the realities of bank money and organized securities markets, but also rendered useless as a theory by ruling out effective demand as the key determinant of employment by assumption.

Hopelessly trapped in an agricultural ("corn economy") worldview that has the "not consumed" (i.e., saved) corn becoming the investment of the next period, loanable funds theory was no better, Keynes found. For in monetary production economies real capital gets produced and therefore requires, like any other economic activity, advance finance rather than prior saving. Hence those engaged in economic activity need to first find the money to then spend, produce, or acquire assets. They need to either convince those who have money to hand it over, or those who can produce money to do so - at a price of course: "the" rate of interest. 
This key insight underlies Keynes's "liquidity [preference] theory of the rate of interest": interest rates are determined by the financial system as the price that, at the margin, balances desires of those who want to become more liquid and those willing to become less so, including the producers of liquidity, the banking system. It is not saving decisions at issue here, but portfolio decisions concerning the form in which wealth is held and finance raised, with the banking system providing "liquidity par excellence": money. In other words, economic activity and employment, capital accumulation and development are conditioned by the liquidity provided by the financial system but do not depend on — or are somehow "financed by" - saving, as loanable funds theory would have it (Chick 1983; Bibow 2009a).

Modern mainstream macroeconomics may have written money and the quantity theory of money out of the play - replaced by an independent central bank setting a policy interest rate with a view of hitting its inflation target (by following some "Taylor rule" while chasing Wicksell's "natural rate"). Yet, upholding loanable funds theory, the mainstream still has the financial system channeling saving flows into investment, with banks churning deposits into loans. Applied globally, financial globalization was promised to enable poor countries to invest more and catch up faster - by borrowing richer countries' ample saving resources. The promoters' advice for developing countries aspiring to catch up to advanced ones then seems straight forward: to liberalize, privatize, and open up their economies to the market forces of wisdom ruling in today's hyperglobalized world (Fischer 1997; Summers 2000).

Liquidity preference theory, applied in a global setting, offers a rather different perspective on the supposed virtues of financial globalization. The point about money is, as Keynes emphasized, that money (the "money rate of money interest") sets the floor below which other rates of return on assets in general will not fall. In other words, the terms of liquidity provision as determined by the financial system condition the production of new capital assets and hence employment and development. The question is whether liquidity production should better be organized locally or globally.

For countries lacking capabilities to produce real capital assets, access to global finance appears to offer an alternative to the payment for imports solely by means of exports. But under 
globalized finance, returns on assets, denominated in different national currencies or not, will also compete globally and be subjected to the whims of arbitrage, hedging, and speculation. In fact, national currencies themselves, as financial assets constantly assessed by global financial market players, will be subject to the same forces, too. And some currencies may be considered safer and more liquid than others.

"Disciplined by" financial market players, representing the international powers of wealth (mainly located in rich countries) acting freely across borders, national authorities will see their options and "policy space" shrink accordingly. For those with sufficient faith in the invisible hand (or vested interest in the global rule by the powers of wealth) this outcome may seem attractive (Hayek 1977). Bolstered by his own immense practical experience, in addition to superior theoretical insight, Keynes was skeptical that globalized finance would necessarily foster development and the general good (Bibow 2009a, 2017).

Keynes illustrated the importance of money and finance in monetary production economies in terms of his "own rates" analysis, featuring the concept of the "liquidity premium" and yielding a structure of asset prices (Bibow 2009a; Kaltenbrunner 2015; De Paula, Fritz, and Prates 2017).

Keynes distinguishes different types of assets as possessing the following attributes in different degrees: yield $q$, carrying $\operatorname{cost} c$, and a liquidity premium $l$. To determine the expected returns on different types of assets over a period of time, in addition, the expected percentage of appreciation or depreciation relative to some standard of value - normally the national moneyis required. The total expected return on an asset, or its "own rate of (money) interest," is the sum of these four elements (1): $R_{i}=q_{i}-c_{i}+l_{i}+a_{i}$, where the resulting (net) yields are defaultrisk adjusted and incorporate the cost of financial intermediation. An equilibrium requires the demand prices of all different types of assets to be such that their total expected returns are all equal. In such a general portfolio equilibrium, all assets are held and wealth holders have no incentive to reshuffle their portfolios at the current structure of asset prices - at least for a nanosecond. 
Money appears in a pivotal position in this general portfolio allocation approach. First, money is the standard of value or unit of account. Second, Keynes identifies money as the asset with the highest liquidity premium. Having a certain (money) value under (almost) any circumstances makes money an attractive store of value in a world of fundamental uncertainty. The strength of the desire to hold money is not constant irrespective of circumstances though. Rather, as an indicator of our trust in the future, it is subject to abrupt change.

In this regard, bank money is par excellence "liquid" in the eye of the (nonbank) public, while central bank money provides the ultimate settlement asset and liquidity par excellence from the banks' perspective. Treasury bills and other money market instruments may be more or less close substitutes. The liquidity premium is not an actual yield but a notional reward, an amount of actual yield wealth holders are willing to forego for having money instead of less liquid assets at their disposal: "for the potential convenience or security given by this power of disposal" (Keynes [1936] 1971: 226).

Money may also provide an actual yield on top of its liquidity premium: the short-term interest rate traditionally set by the central bank as the expression of its monetary policy stance. Competition will align the yield on bank money (and close substitutes) with the set policy rate. (The yield on central bank money_if nonzero-will depend on the central bank's particular operating procedures.)

Keynes's own-rates analysis highlights that monetary policy stands at the very center of the structure of asset prices. Its influence on economic activity, as seen from this perspective, arises because money's own rate of interest - its liquidity premium plus any cash yield (together with typically negligible carrying cost) — sets the floor below which the own rates of interest on other financial instruments and assets in general cannot decline.

Financial instruments traded in financial markets provide alternative "liquid" stores of value that typically promise higher yields. Investments that are final and permanent commitments by society are thereby made fluid for the individual fleeting "investor." The liquidity of markets can be compatible with stable prices of debts and assets at times. But market conventions rooted in 
imagination can dissolve rapidly, prices become unhooked and volatile, and market liquidity totally evaporates at times of stress. At no time is there any guarantee that prices will reflect some true and unique underlying real reality —as the mainstream view, with its "efficient market theory" of finance, suggests. Asset market play is self-referential; asset prices restless and prone to excess volatility, bubbles, and crashes; and liquidity and leverage are disposed to sponsor mania and fragility — as the experienced global financial market player John Maynard Keynes understood all too well (Minsky [1975] 2008; Carvalho 2016).

Financial conditions as determined by the financial system together with entrepreneurs' expected rates of return on potential projects ("marginal efficiencies of capital") determine the demand prices for capital goods, while the economy's cost structure (wages, etc.) determines their respective supply prices. The production of capital goods ceases at the point at which their demand prices drop below their supply prices. There is no guarantee that by some law of nature this point will be at full employment. The financial system, determining the terms on which money is made available to the economy, can err in its allocative role, sponsoring wasteful activities. Under monetary policy guidance and regulated to some degree, it can also go astray regarding macro stability and usher in deep economic crises.

Under globalized finance the portfolio equilibrium condition depicted above will be a worldwide structure of asset prices expressed in some common standard of value. For reasons that will be elaborated upon below, the US dollar has served in that role since WWII, with the US Federal Reserve setting the anchor rate for global finance and the floor below which the own rates of interest on other assets cannot decline globally (Ocampo 2001; Terzi 2006).

In principle, national central banks may set their policy rates at different levels. But they will now all be seen by the markets with reference to the US dollar anchor. Unless exchange rates are stabilized by the authorities, their expected rates of appreciation or depreciation will be part of the $a$-terms of assets denominated in some national currency. Different national monies may carry different and time-varying liquidity premiums in the judgment of global market players, depending on the perceived relative potential convenience or security based on their respective power of disposal. 
The current regime of globalized finance and US dollar hegemony contrasts starkly with Keynes's envisioned ideal postwar global monetary order-which we will briefly revisit in the next section.

\section{THE GLOBAL MONETARY ORDER ENVISIONED BY KEYNES}

Keynes's draft proposals for the postwar global monetary order were based on decades of research and informed by the theoretical breakthroughs of his General Theory. Keynes's two foremost objectives were, first, to put the gold standard to rest and replace it by a new-more flexible - order that featured no hegemonic national currency and, second, to tame global finance so that national macroeconomic policies could be applied to maintain full employment in line with his General Theory. The key principles of his scheme are briefly rationalized here.

In the Keynes plan, national currencies would be pegged to a new international unit of account: bancor. Exchange rates were meant to be stable but not rigid. Parity changes would arise as semiautomatic adjustments designed to maintain internationally balanced trade and payments positions. Keynes held that wage and price inflation differentials would be the key driver of exchange rate adjustments.

Up to certain generous limits, international liquidity would arise in line with international payments imbalances, as countries could freely draw on their unconditional bancor overdraft lines provided by an international central bank established to fulfil this bridging function. Rules would apply to surplus and deficit countries symmetrically to contain and reverse imbalances. For instance, surplus countries would face pressures to expand domestic demand while their currencies appreciate.

Keynes foresaw that international (net) payments would be channeled through national central banks rather than liberalized currency markets. Short-term ("hot money") capital flows had to be strictly contained. Keynes saw some room for managed long-term private capital flows supporting development and complementing official development aid. Keynes also considered 
other potential supplementary global institutions designed, for instance, to stabilize commodity prices.

Overall, the envisioned international monetary order was devised to facilitate global trade but tame global finance. Global liquidity to facilitate trade arises endogenously — curtailing any precautionary demand for national reserves. Official development aid (ODA) and managed longterm capital flows would only enable real capital and technology imports above and beyond what is paid by current exports. By establishing an international order based on symmetry and designed to maintain international balance, countries would be prevented from pursuing "beggarthy-neighbor" strategies, but enabled to focus their national macro policies on maintaining internal balance. Finance was meant to be not the master, but the servant of commerce and development. Finance was to be primarily national (Keynes [1933] 1982, [1942] 1980; Bibow 2009a).

In the course of the bilateral negotiations culminating in the Bretton Woods conference it became ever clearer to Keynes that his own scheme stood no chance with the American side. His best hope was that America would really sign up to their own plan in the end, masterminded by Harry Dexter White. Keynes defended the Bretton Woods agreement in the British Parliament as a

clear improvement over the gold standard — that "barbarous relic" (Keynes [1923] 1971) —and as a workable regime that would support postwar prosperity. Overall, the Bretton Woods regime fulfilled his hopes - until its breakdown in the early 1970s.

\section{EVOLUTION OF THE GLOBAL US DOLLAR ORDER: FINANCE TAMED AT FIRST, THEN HYPERGLOBALIZED}

By design, the postwar international monetary order was based on the US dollar. While officially convertible into gold among central banks until August 15, 1971 (a supposed safeguard that got dropped when it became too inconvenient), the US dollar has claimed the top spot in the global pecking order of currencies ever since. In fact, following the 1970s global macroeconomic turmoil that featured US weakness and lack of global leadership, US dollar supremacy was 
restored and supercharged under increasingly globalizing finance starting in the 1980s (Isard 2005; Bibow 2009a; Eichengreen 2012).

The inbuilt asymmetry in international financial affairs bestows the hegemon with privileges and responsibilities.

International US dollar liquidity is anchored by Federal Reserve policy and dependent on the US balance of payments position, granting the hegemon a unique measure of policy space and capacity for global spillovers. The rest of the world's demand for US dollar liquidity, official and private, is an indicator of perceived vulnerability on their part; no longer primarily driven by needs to facilitate commerce, the dollar "premium" and exchange rate are measures of global financial players' degree of disquietude. Foreign official authorities hold US dollar liquidity as a precaution. For private financial market players, too, access to US dollar liquidity, in good times and in bad, is a vital source of power they can wield globally. The Federal Reserve stands as their ultimate caretaker, with the nationality of financial market player and capacity for spillbacks on US interests as key determinants of the measure of care provided.

It was more of a symbiosis of interests at the post-WWII outset. The European periphery was lacking both dollar liquidity and real resources for reconstruction. The United States had amassed the world's gold and needed an outlet for its exports to sustain full employment. "Marshall Plan" aid bridged affairs mutually and facilitated joint revival. Then US foreign direct investments became the main source of dollar liquidity, with the United States acting as "banker to the world" by meeting the periphery's trade-driven and hence limited dollar liquidity demand - supplemented to countries under duress by IMF resources that were still adequate under the circumstances of the time.

Exchange rates proved far too rigid though. At first this was foremost an issue within the (European) periphery. Associating devaluation with national defeat, deficit countries delayed the inevitable. Worse, surplus countries stemmed revaluation with utmost determination for mercantilist ambitions. For instance, (West) Germany applied both capital controls and amassed gold and US dollar reserve holdings greatly in excess of precautionary needs - to fire up its 
export engine instead of managing domestic demand. Overall, however, the system could withstand tensions within the periphery while the World Bank and ODA lent some support to the developing world.

The Bretton Woods system only faltered and eventually collapsed when the hegemon saw its trade surplus turn negative while offshore ("euro") dollar markets - emerging as capital controls and tight postwar banking regulations were gradually rolled back—provided an avenue for reviving global financial players to also bet against the supreme but overstretched global reserve currency.

US weakness created a global policy vacuum that was part of the pronounced macro instabilities of the 1970s. Hit by a large negative terms-of-trade shock, advanced economies' growth stalled while unemployment and inflation soared. It was convenient that large developed-country banks applied their newfound global liberties to extend loans to willing borrowers in the developing world, helping to sustain global growth at first, but laying the groundwork for the 1980s developing-country debt crises.

The US dollar surged back to power and glory on the back of a mixture of tight money ("Volcker shock") and fiscal expansion (Reagan's "supply-side" mantra). The surge of the US dollar and stock markets also marked the proper start of neoliberalism as both the United States and Western Europe raced to liberalize their financial systems and claw back on external controls (Abdelal 2007). An ever-expanding global financial system based on US dollar liquidity came to replace the demolished Bretton Woods monetary system. Mounting “financialization," featuring rising inequalities and a negative resource transfer from the developing world, has been the rule ever since (Kregel 2004; Bibow 2009b, 2012; Akyüz 2018).

The US dollar experienced a roller-coaster ride over the course of the 1980s, a decade that saw Japan at first emerge as a potential challenger to US dollar and Wall Street supremacy, but then end the decade in the doldrums. For many developing countries, especially in Latin America, it was a "lost decade." Super-high interest rates and the strong dollar together with plunging 
commodity prices left numerous developing (debtor) countries insolvent. Developed (creditor) countries focused on containing the impairment of their own "too-big-to-fail" banks.

The year 1991 was a time of recession and, flattered by official transfers from allies for US-led military action in the Middle East, it was the last time that, for once, the US current account deficit briefly disappeared. Under globalized finance, huge US current account deficits have become the norm - providing corresponding scope for the rest of the world to earn US dollar liquidity in a precarious world economy.

The 1990s were the heydays of neoliberalism as financial liberalization accelerated all round. Western Europe completed its "common market," agreed to launch a common currency, and embraced a vast enlargement of its union toward the east (where the Soviet Union had collapsed). Meanwhile, the IMF and World Bank embarked on spreading the "Washington Consensus" (Williamson 1989) in the developing world. As an irony of history, financial crises in newly liberalized emerging economies were piling up just at the time when the IMF tried to also officially enlarge its mandate to include financial account liberalization, though its original remit in the Bretton Woods spirit had solely focused on current account liberalization to facilitate managed multilateral trade (Fischer 1997).

The so-called "emerging markets" crises around the turn of the millennium—crises instigated by the forces of global finance - marked an important watershed. Crisis countries suffered very deep recessions. They found their own national defenses inadequate to buffer financial stress while the conditional collective insurance "help" provided by the IMF often inflicted more pain than any relief.

Responses featured "defensive" macroeconomic policies. Emerging economies started amassing US dollar reserves, as they had learned that under globalized finance precaution had to be sized by the vagaries of finance rather than trade. Containing vulnerabilities arising from current account deficits and external indebtedness competitiveness became a policy priority. These efforts proved successful as the external and fiscal positions of emerging economies generally improved markedly. So much so that the IMF was running out of business in the 2000s and had 
to downsize as their customers turned away from its collective insurance products and "selfinsured" instead (Bibow 2009b).

How could the global economy still experience an impressive boom in the 2000s despite the widespread recourse to defensive macro policies? The global spreading of the neoliberal focus on competitiveness was creating the deflationary forces and rising inequalities that Keynes's fallacy-of-composition argument had warned against, but a global boom played out. The answer is that the US hegemon met its responsibilities and obediently played its role as global growth engine, and borrower and spender of last resort.

For one thing, in response to the "dot.com" bust, the G. W. Bush administration administered a huge fiscal easing. For another, the Federal Reserve responded to the threat of deflation by cutting its policy interest rate to a record low 1 percent. This duly translated into globally easy monetary conditions. Global financial players, fired up by the US Fed, showed great keenness in acquiring assets in emerging economies. They responded by amassing evermore US dollar liquidity as a precaution and to maintain their competitiveness and export growth.

Prior to the global crisis, the relationship between the hegemon and the developing world was symbiotic in the sense that the latter experienced growth while containing their external vulnerability through defensive macro policies. Meanwhile, the hegemon magnified its "exorbitant privilege" through "dollar levering": private acquisitions of higher-yielding external assets would push dollar liquidity into the system only to get mopped up by cautious authorities as bulging foreign exchange reserves (Bibow 2011b). One party's insurance premium paid is the other party's supercharged privilege. Compared to the restrained trade-related liquidity needs under Bretton Woods, hyperglobalized finance provided a sheer feast to the hegemon. 


\section{GLOBAL FINANCIAL CRISIS AND ITS AFTERMATH: THE END OF AN ERA?}

It appears the era of dollar supremacy under hyperglobalized finance reached a new watershed with the global crisis and the policy choices made in response. The crisis originated at the core of the global financial system, a trans-Atlantic crisis of the world's most "sophisticated" finance: made in the United States and Western Europe. In the United States, Wall Street had levered up the US household sector by innovative credit products sponsoring a housing bubble. European banks had not only provided a helping hand in the US bubble, but simultaneously also sponsored homegrown bubbles, especially inside Europe's peculiarly ill-designed currency union. When the bubbles burst, the developing world was affected as an innocent bystander. Through the trade collapse the impact was felt worldwide. Developing countries not yet integrated financially were at an advantage compared to emerging economies suffering "sudden reversals" in capital flows, as well as plunging currencies and asset prices - as global financial players fled home and sought safety, primarily in the US dollar (Bibow 2011b).

Emerging economies hit by crises generally go through IMF "adjustment programs" that require sharply contractionary macro policies. As an important part of its privilege, the hegemon was free to implement sharply expansionary macro policies instead. Initially the United States (and crisis-stricken Europe to some extent) implemented both monetary easing and lending of last resort programs, as well as fiscal stimulus packages. In this way, the steep plunge in global trade and production was halted by mid-2009 and the initial bounce back in 2010 was quite vibrant.

For emerging economies, the policy responses organized at the center were a mixed blessing. The revival of export markets in developed economies was surely welcome. But the macro policy mix adopted in the United States and Europe created fresh challenges to the developing world, especially when fiscal policy began to shift back into austerity mode in 2010. This premature and ill-guided fiscal policy U-turn forced the US Fed to engage in extreme monetary easing policies with even greater force and for far longer. 
In the early 1980s, super-tight money administered by the US Fed was the unsolicited challenge, with bankruptcies in the developing world the consequence. Post-2008, when finance had become far more globalized, super-easy money set off by the US Fed's leader (should have) set off bubble alarm bells among emerging economy followers. Keynes's foremost concern had been that tight money would constrain economic activity. In the aftermath of the global crisis, zero interest rate policies (ZIRP), quantitative easing $(\mathrm{QE})$, and finally even negative interest rate policies (NIRP) pursued at the center presented the periphery with the opposite risk of instability by financial rentier mania.

The tide of global capital flows already began to turn in mid-2009, when the Federal Reserve was merely at the stage of "QE1," pushing the dollar lower and keeping it low for the next five years. Facing a fresh avalanche of capital flows, asset prices in recipient countries surged, financial conditions eased, and credit booms got unleashed as emerging economies' currencies generally appreciated strongly. Emerging economies had not lost their appetite for defensive macro policies. But the extreme easing at the center left them little choice in containing upward pressures on their currencies without obediently easy money. Fresh vulnerabilities built up as a result. Household sector debts were but one issue. Especially the nonfinancial corporate sector in emerging economies engaged in large-scale US dollar borrowing as part of the "carry trade" game (McCauley, McGuire, and Sushko 2015a, 2015b; Cavallo, Eichengreen, and Panizza 2016; Ghosh, Ostry, and Qureshi 2017). Importantly, not real investment but corporate financialization experienced a boom. The relentless "searching for yield" keenness of global financial players also opened up new frontiers in developing countries along the way, enticing poor countries to load up on foreign debts - whenever it is convenient from a rich-country perspective.

China emerged as global growth engine number one in the aftermath of the global crisis. To a significant extent sheltered from global finance through financial account management prior to the crisis (Ma and McCauley 2007), China implemented huge fiscal stimulus measures in response and saw sharp rises in corporate sector indebtedness, rebalancing its economy toward domestic demand while undergoing controlled currency appreciation. With China as chief global growth engine, and Wall Street and the US dollar continuing to set the tune of global finance, the developing world must now somehow straddle these two dominant poles in the world economy. 
Turning points in Federal Reserve policy are always a special challenge in the periphery. So fresh instabilities arose in 2013 with the approaching tapering of "QE3," and matters worsened as the Fed's interest rate "lift off" neared and the dollar appreciated sharply in 2015 (Rajan 2014; Ghosh, Ostry, and Qureshi 2017). Many emerging economies' fiscal and external positions had deteriorated markedly under the regime of extreme monetary ease of previous years. Fragilities only got worse when China experienced a marked growth slowdown and the renminbi depreciated ominously in 2015-16. The cycle of global instability that had last visited emerging economies around the turn of the millennium, then paying its homage at the center, was now making a return in the developing world.

Only that this time round - in contrast to the 2000s — the United States seems neither able nor willing to play the role of global growth engine while practicing benign neglect regarding its external position. The Trump administration has not only made it its goal to shrink America's trade deficit through bilateral strong-arm dealings, but also pursues a course of conflict with China. Torn between the two power poles in the global economy, risks for emerging economies are mounting.

\section{HYPERGLOBALIZED FINANCE AND THE DEVELOPING WORLD: CHALLENGES AND OPTIONS}

Today's position of emerging economies under hyperglobalized finance starkly contrasts

Keynes's bancor vision. Their lack of policy space and overall precariousness are two sides of the same dollar coin.

Dollar hegemony and hyperglobalized finance preclude emerging economies from establishing a structure of asset prices and financial conditions that might suit their own domestic conditions. As fair game of global financial players, their economies are integrated in the global structure of asset prices and financial conditions, as determined for them by the US Fed and Wall Streetbased on US domestic conditions. 
Mainstream monetary theory includes a branch called "optimum currency area theory," which investigates the conditions that either help or hinder countries in sharing a common currency. Unfortunately, this theory is little else but a cousin of the mainstream "trilemma view," promising that floating exchange rates would secure countries' policy autonomy even under globalized finance.

While this notorious view has recently been challenged even within the mainstream (Rey 2014, 2016), liquidity preference theory suggests that floating exchange rates can only grant emerging economies limited policy space anyway, at best. The issue is not only a matter of monetary policy dependency per se, but also one of exposure to the whim and fickleness of global financial conditions and global financial players' sentiment (Harvey 2009).

In addition, emerging economies are paying dearly for "self-insurance," with foreign reserves sized to the vagaries of hyperglobalized finance — when no such burden would arise at all under Keynes's scheme other than paying interest on any bancor overdraft credit line actually used.

It would appear, then, that hyperglobalized finance is charging emerging economies a rather steep price, and for what exactly? Even mainstream studies have trouble providing any compelling evidence of the promised benefits (Kose et al. 2006; Prasad, Rajan, and Subramanian 2007; Cavallo, Eichengreen, and Panizza 2018).

The neoclassical loanable funds view that global finance would enable poor countries to draw on rich-country saving confuses finance and real capital. To actually boost capital formation and technology in poor countries involves a policy mix geared toward mobilizing local resources paired with sustainable (i.e., long-term, nonexploitative) external finances that can augment the acquisition of foreign capital goods and technology beyond what exports currently pay for. Acquiring foreign expert services in designing policies and institutions, including financial system policies, can make a valuable contribution toward this end. But importing "foreign expertise" on the back of fickle capital flows is unlikely to play a constructive part in development apart from remunerating foreigners for unwarranted liquidity "services": liquidity 
can be best produced locally under the control of the national monetary authorities. Mainstream theory remains trapped in prehistorical loanable funds confusions until this day.

Ultimately the argument for financial account liberalization has to draw on political economy concerns: the notion that free markets serve to discipline politicians-allegedly forever tempted to pursue their own rather than the public good. Admittedly, this concern is a real one. Liquidity preference theory reveals the role government can and should play in development, specifically in managing national monetary and financial affairs, but it does not guarantee that governments will comply. No doubt governments can be corrupt and/or incompetent, as in developed economies, too.

By the same stroke one should then also admit to the fact that hyperglobalized finance is hardly a reliable source of wisdom either. The global crisis has shown that the most sophisticated finance can be little else but an organized scam. The trade-off in hiring global finance to contain the damage potentially done by bad government seems to be that of undermining the scope for constructive government toward development. For all but the worst governments, wisdom will likely rest in keeping global finance at bay and organizing liquidity production locally instead (Bibow 2012). 


\section{REFERENCES}

Abdelal, R. 2007. Capital Rules: The Construction of Global Finance. Cambridge, MA: Harvard University Press.

Akyüz, Y. 2018. "External balance sheets of emerging economies: Low-yielding assets, highyielding liabilities." PERI Working Paper Series no. 476. Amherst, MA: Political Economy Research Institute.

Bernanke, B. 2005. "The global saving glut and the U.S. current account deficit." Remarks at the Sandridge Lecture, Virginia Association of Economists, Richmond, VA, March 10. Available at: https://www.federalreserve.gov/boarddocs/speeches/2005/200503102/

Bibow, J. 2009a. Keynes on Monetary Policy, Finance and Uncertainty: Liquidity Preference Theory and the Global Financial Crisis. London and New York: Routledge.

_ 2009b. "Insuring Against Private Capital Flows: Is It Worth the Premium? What Are the Alternatives?" International Journal of Political Economy 37(4): 5-30.

—. 2011a. "Of unsustainable processes and the U.S. dollar." In D. B. Papadimitriou and G. Zezza (eds.), Contributions to Stock-Flow Modeling: Essays in Honor of Wynne Godley. London: Palgrave Macmillan.

—. 2011b. "Global Imbalances, the U.S. Dollar, and How the Crisis at the Core of Global Finance Spread to 'Self-insuring' Emerging Market Economies.” InterventionEuropean Journal of Economics and Economic Policies 7(2): 325-59.

_ 2012. "The case for capital account management in emerging market economies: The experience of the BRICs." Intervention-European Journal of Economics and Economic Policies 9(1): 57-90.

—. 2017. "Symmetric global order with national self-determination and no hegemon: vision and reality." In the Special Issue "Keynes's Relevance to the Contemporary World," Annals of the Fondazione Luigi Einaudi, LI, 1-2017: 177-206, Fondazione Luigi Einaudi.

Carvalho, F. J. C. de. 2016. "On the nature and role of financial systems in Keynes's entrepreneurial economies." Journal of Post Keynesian Economics 39(3): 287-307.

Cavallo, E., B. Eichengreen, and U. Panizza. 2018. "Can Countries Rely on Foreign Saving for Investment and Economic Development?" Review of World Economics 154(2): 277-306.

Chick, V. 1983. Macroeconomics after Keynes. Cambridge, MA: MIT Press. 
De Paula, L. F., B. Fritz, and D. M. Prates. 2017. "Keynes at the periphery: Currency hierarchy and challenges for economic policy in emerging economies." Journal of Post Keynesian Economics 40(2): 183-202

Eichengreen, B. 2012. Exorbitant Privilege. The Rise and Fall of the Dollar and the Future of the International Monetary System. Oxford: Oxford University Press.

Fischer, S. 1997. "Capital-Account Liberalization and the Role of the IMF." Remarks for the IMF Seminar, "Asia and the IMF," Hong Kong, September 19. Available at: https://www.imf.org/en/News/Articles/2015/09/28/04/53/sp091997

Ghosh, A. R., J. D. Ostry, and M. S. Qureshi. 2017. "Managing the Tide: How Do Emerging Markets Respond to Capital Flows?” IMF Working Paper 17/69. Washington, DC: International Monetary Fund.

Harvey, J. T. 2009. Currencies, Capital Flows and Crises: A Post Keynesian Analysis of Exchange Rate Determination. London: Routledge.

Hayek, F. A. von. 1977. Denationalization of Money: An Analysis of the Theory and Practice of Concurrent Currencies (Hobart paper special no. 70). London: The Institute of Economic Affairs.

IMF. 2012. "The Liberalization and Management of Capital Flows-An Institutional View." IMF Policy Paper, November 14. Washington, DC: International Monetary Fund. Available at: https://www.imf.org/external/np/pp/eng/2012/111412.pdf

Isard, P. 2005. Globalization and the International Financial System-What's Wrong and What Can Be Done? Cambridge, UK: Cambridge University Press.

Kaltenbrunner, A. 2015. "A Post Keynesian Framework of Exchange Rate Determination: A Minskyan Approach.” Journal of Post Keynesian Economics 38(3): 426-48.

Keynes, J. M. (1923) 1971. “Tract on Monetary Reform.” Reprinted in The Collected Writings [CW] of John Maynard Keynes, D.E. Moggridge (ed.). London: Macmillan. (1933) 1982. "National Self-Sufficiency." The New Statesman and Nation, CW, vol. 21: 233-46.

—. (1936) 1971. The General Theory of Employment, Money and Interest. CW, vol. 7. (1942) 1980. "Plan for an International Currency (or Clearing) Union.” CW, vol. 25: $108-39$.

Kose, M. A., E. Prasad, K. Rogoff, and S. J. Wei. 2006. "Financial Globalization: A Reappraisal.” IMF Working Paper 06/189. Washington, DC: International Monetary Fund. 
Kregel, J. 2004. "External Financing for Development and International Financial Instability." G-24 Discussion Paper no. 32. New York: United Nations Conference on Trade and Development.

Ma, G., and R. N. McCauley. 2007. "Do China's capital controls still bind? Implications for monetary policy autonomy and capital liberalization.” BIS Working Paper 233. Basel: Bank for International Settlements.

McCauley, R.N., P. McGuire, and V. Sushko. 2015a. “Global Dollar Credit: Links to US Monetary Policy and Leverage." Economic Policy 30(82): 187-229.

- 2015b. "Dollar credit to emerging market economies." Bank for International Settlements' Quarterly Review, December: 27-41.

Minsky, H. P. (1975) 2008. John Maynard Keynes. New York: McGraw-Hill.

Ocampo, J. A. 2001. "International Asymmetries and the Design of the International Financial System.” CEPAL Serie Temas de Coyuntura no. 15. Santiago de Chile: The United Nations Economic Commission for Latin America and the Caribbean (CEPAL).

Prasad, E., R. Rajan, and A. Subramanian. 2007. "Foreign capital and economic growth." Brookings Papers on Economic Activity 1: 153-230.

Rajan, R. 2014. “Competitive monetary easing — is it yesterday once more?" Remarks at the Brookings Institution, Washington, DC, April 10. Washington, DC: Bank for International Settlements. Available at: https://www.bis.org/review/r140414b.htm

Rey, H. 2014. "Dilemma not trilemma: the global financial cycle and monetary policy independence." In Global dimensions of unconventional monetary policy, Proceedings of the Federal Reserve Bank of Kansas City’s Jackson Hole symposium.

- 2016. "International channels of transmission of monetary policy and the Mundellian trilemma." IMF Economic Review 64(1): 6-35.

Summers, L. H. 2000. "International Financial Crises: Causes, Prevention, and Cures.” American Economic Review 90(2): 1-6.

Terzi, A. 2006. "International financial instability in a world of currencies hierarchy." In L.-P. Rochon and S. Rossi (eds.), Monetary and Exchange Rate Systems: A Global View of Financial Crises. Cheltenham, UK: Edward Elgar.

Williamson, J. 1989. "What Washington Means by Policy Reform.” In J. Williamson, Latin American Readjustment: How Much Has Happened? Washington, DC: Peterson Institute for International Economics. 